\title{
Interactions among forest enterprises: Do they compete or cooperate with sales by auction on log prices?
}

\author{
Güven Kaya' ${ }^{1 巴}, K^{\infty}$ enan $\mathbf{O k}^{2}$
}

Kaya G., Ok K., 2021. Interactions among forest enterprises: Do they compete or cooperate with sales by auction on log prices? Ann. For. Res. 64(2): 123-138.

Abstract A few studies on log auction sales have addressed competition and cooperation among seller enterprises. Interactions among state forest enterprises in the same or neighboring regions have been neglected. This study aimed to determine the extent of competitive and cooperative relationships among forest enterprises (FEs) in relation to the prices of Austrian pine (Pinus nigra), Scots pine (Pinus sylvestris), and fir (Abies sp.) log sales by auction. The study investigated log sales between 2017 and 2018 conducted by 26 FEs in Turkey. Competitive and cooperative relations among FEs, based on auction time, volume and prices, were tested via correlation and multiple regression analysis. The results indicate that an FE may display competitive or cooperative relationships with other FEs, regardless of whether or not such FEs are border neighbors. We determined that an FE may compete with another FE in one log type, while cooperating in another wood type. Our study shows that log sales revenues of some FEs can be increased by changing the length of time between the sales of two FEs, by not holding the sales of two FEs on the same day, and by differentiating the volume of rival and complementary wood types. Our study found that better management of competition and solidarity between forest enterprises would help create more financial resources for sustainable forest management without having to harvest more trees.

Keywords: forest enterprises, $\log$ price, auction sales, competition, cooperation

Addresses: ${ }^{1}$ Marmara Forestry Research Institute, İstanbul, Turkey $\mid{ }^{2}$ Department of Forestry Economics, İstanbul University-Cerrahpaşa, İstanbul, Turkey.

$\varpi$ Corresponding Author: Güven Kaya (guvenkaya@ogm.gov.tr).

Manuscript received April 07, 2021; revised December 11, 2021; accepted December 17, 2021. 


\section{Introduction}

Turkey's General Directorate of Forestry (GDF), established in 1840 as a public organization, is responsible for the management of all state-owned forests (99.9\%) and auditing of all forests in the country. The GDF operates in similar fashion to a holding company, overseeing 246 forest enterprises' (FE) affiliations with 28 regional directorates of forestry (RDF) in Turkey (GDF 2018). The GDF fulfills the "public duties" assigned to it by the law, and also plays a role in the market, such as that of a commercial enterprises association, in the sense that it tries to create the financial resources necessary for the sustainable management of forests.

There are organizations similar to Turkey's GDF in other countries. According to the European State Forest Association (EUSTAFOR), there are 22 state FEs affiliated to a central public body or institution in Hungary, six in Bulgaria, 26 in Slovakia, and four in Czechia. There are 430 provincial units affiliated with a central institution in Poland, 67 in Serbia, and 169 in Croatia (EUSTAFOR 2020). The Coillte company, which manages Ireland's state forests, consists of six geographically divided enterprises or operation units (Coillte 2020).

In order to ensure the sustainability of forests, FEs have to consider economic relations and financial resources as well as ecological variables. Therefore, the forest financing issue has become an increasingly relevant topic of discussion in international processes, such as the United Nations Forum on Forests. Although tools such as taxes, grants, international aids and funds, donations of any kind, and payments for ecosystem services are discussed constantly, the most important source of income for FEs operating in Turkey and the above-mentioned countries is the sale of wood as raw material. Thus, wood sales should be managed effectively via the market mechanism. It is mandatory for FEs or strategic units that strive for the same purpose to be with the same superior institution and operate under a common understanding that "positively" affects one another; in other words, the goal of FEs must be to ensure cooperation amongst themselves, rather than competition.

State FEs in Turkey were established to create the financial resources necessary for the development and improvement of forests unable to make a profit due to their natural structure, they act as a more effective form of enterprise in forest lands, one that is capable of yielding money (Illkmen 1946). Each FE affiliated to the GDF can sell forest products in the free market, and further maintain forestry activities in their region with sales revenue, as well as finance other forestry activities with the financial resources they provide to the GDF. Each FE has separate balance sheets. However, the financial outcomes of these FEs accordingly impact their supreme organization, the GDF, to either make a profit or incur a loss. The fact that an FE affiliated to the GDF is competing with other affiliated FEs and taking a share from its market may look profitable in the short term, but is likely to cause revenue loss for the GDF. The GDF's most recent strategic plan report states that a fund of 50.5 million TL will be needed in order to reach its targets for the 2019-2023 period, and that $61 \%$ of these financial resources are planned to come from the revenues of FEs (GDF 2018). This budget requires that, in particular, the auction sales of raw wood material on the free market be managed in coordination. The GDF, which is inherently aware of the interactions between FEs, ordered that the FEs' raw wood material sales by auction must not be conducted on the same day within the same RDF or across neighboring RDFs, and that FEs should develop and act within a plan to ensure this in the same region (GDF 2015).

A limited number of studies support the concerns of the GDF regarding interactions between sales. Ok (1997a) showed that a positive correlation exists regarding the duration ( $\geq 20$ days) between the auctions 
of the Bucak and Gazipasa FEs, which are affiliated to different RDFs but address the same market, and the prices of Gazipasa FE's Turkish pine 3 rd class normal length (3CNL) $\log$ sales by auction. This finding shows that the dates of sales by auction may go further than borders of the FE. Daşdemir (2001) found that the length of time between auctions had a negative effect on the function of fir $3 \mathrm{CNL}$ log sales prices in consecutive sales by auction in the Yenice and Bartin FEs, which are affiliated to the same regional directorate, and that fir 3CNL log sales prices at previous sales of the neighboring FE exhibited positive effects. Daşdemir (2008) determined that the same interactions existed for beech 3CNL log sales prices. These studies have proved that the duration between auctions, as well as the prices set, might effectively impact the prices of sales by auction in neighboring FEs. It was observed that when the price of a wood type increased in the Gazipasa FE, the demand for another wood type increased in the same enterprise (Ok 1997b); from this, we can conclude that substitutional relations between wood types might be taking place in the auctions of neighboring FEs. These studies have proved that not only the sales of neighboring FEs made on the same day, but also the length of time between auctions and the volume of wood on sale, might have an effective impact on auction sales prices.

In their literature review, Leefers \& Ghani (2014) found that most studies have examined the competition between buyers in auctions by employing many independent variables, such as log and sales features, sales date, sales place, sales management, and sales policy states (harvest management, property type, etc.), among others (number of bidders, weather, size of the FE, price of the exported goods, and credit facilities) to explain changes in wood prices. In Turkey, a few studies (Ok 1997a, Daşdemir 2001, Daşdemir 2008) have addressed competition between seller FEs, and the importance of "cooperation between
FEs" has been neglected. Although Belloc (2014) contended that one of the most important problems state FEs face is a lack of information on marketing, Liubachyna et al. (2017) reported that there are insufficient economic analyses upon state FEs in Europe. Olsson (2021) stressed out that the state FEs in Russia try to adopt the modern market economy than in the past, while Kaliszewski and Młynarski (2020) found that some state FEs in Poland, Germany, and Austria tend to diversify their revenue sources. However, both of them neither examined the competition or solidarity between the state FEs. Therefore, we conducted this study to determine the competition and cooperation relationships that may appear between the prices of log sales by auction held by state FEs affiliated to an RDF in Turkey and the sales dates, volumes, and prices of other FEs within or outside of the same RDF.

\section{Materials and Methods}

\section{Study area}

The study area consists of FEs in the Ankara RDF and other neighboring FEs managed by distinct RDFs of the GDF (Figure 1). The Ankara RDF and surrounding FEs were chosen as the study area because they serve as important centers of the forest products industry in Turkey, form collaborative interactions, and are located in the official working area of research institutions. Since industrial wood production is at negligible levels, some outlier FEs (KK, KH, YO, NE, $\mathrm{AK}, \mathrm{KO})$ in the research region were excluded from the study.

The Ankara RDF comprises 805.302 ha, and the neighboring FEs cover 1.482.167 ha of forest land. The primary tree species of the study area are Austrian black pine (Pinus nigra), Scots pine (Pinus sylvestris), and fir (Abies sp.) (GDF 2020).

According to the database of the GDF Forest Information System (GDF 2020), the Ankara RDF sold $334.502 \mathrm{~m}^{3}$ of industrial wood in 2018. 


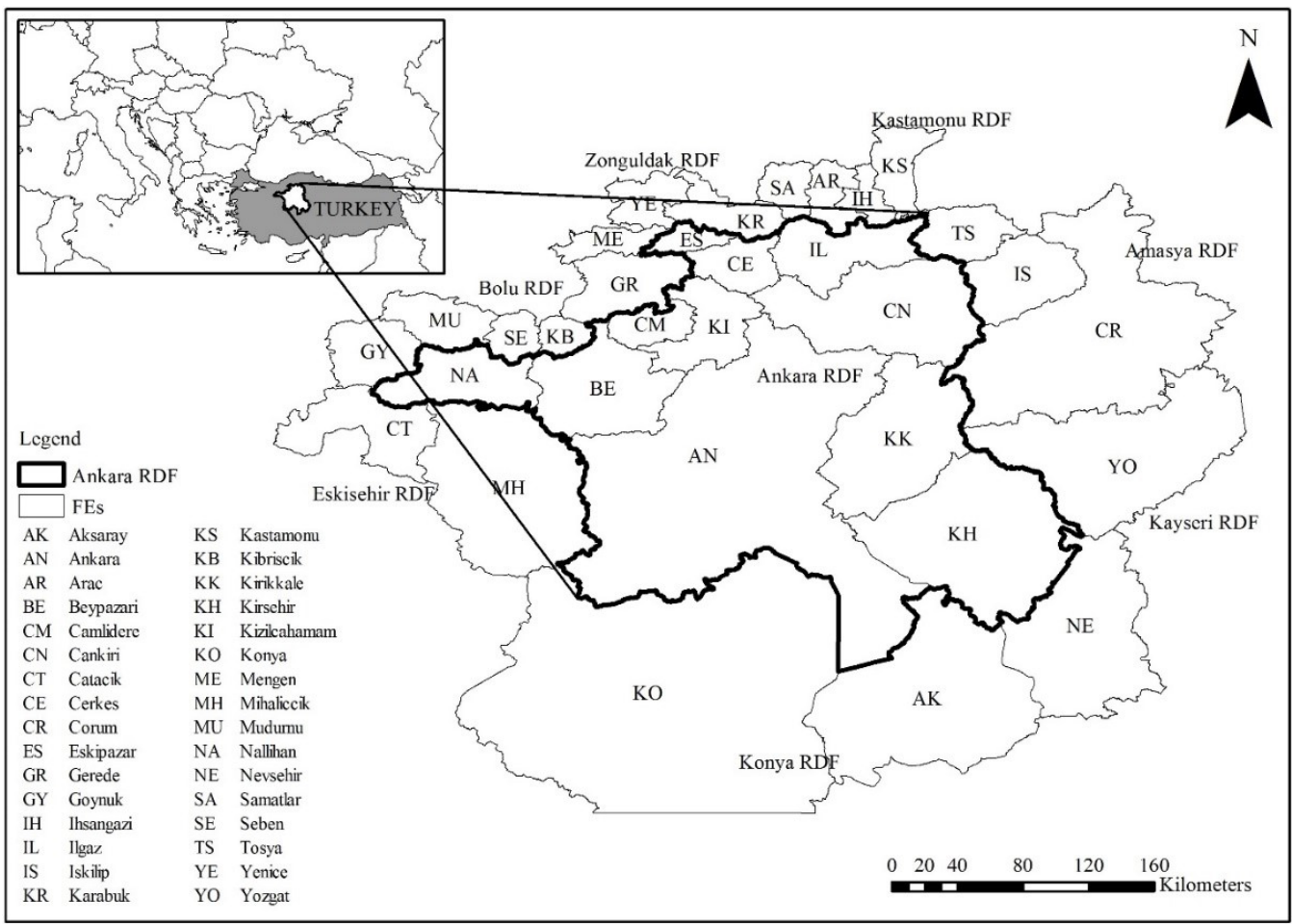

Figure 1 FEs in the study area.

Of this sales volume, $36.5 \%$ was sold by auction under free-market conditions; 65\% $\left(79.091 \mathrm{~m}^{3}\right)$ of the auctions were sales of $\log$ types of raw wood. The types of log with the highest sales (81\%) in 2018 were Austrian pine 3CNL (24.563 $\left.\mathrm{m}^{3}\right)$, Scots pine 3CNL (22.219 $\left.\mathrm{m}^{3}\right)$, and fir 3CNL $\left(18.019 \mathrm{~m}^{3}\right)$. Therefore, only the 3CNL log types of Austrian pine, Scots pine, and fir were included in the study. Depending on the forest management plans, the FEs harvest and sell the 3CNL log types by auction in varying amounts (Table 1).

\section{Method}

The following sales price model (eqn. 1) based on some variables (Table 2) related to sales times, sales volumes, and prices of wood types in auction sales of neighboring forest enterprises was established to explore the competition and cooperation that exists between the FEs (say, i and j) as the main research problem.

$\mathrm{P}_{\mathrm{ik}}=\mathrm{f}\left\{\right.$ Numday $_{\mathrm{ij}}$, Sameday $_{\mathrm{ij}}, \mathrm{Vol}_{\mathrm{j} 1}, \mathrm{P}_{\mathrm{j} 1}$, Pres $\left._{\mathrm{ik}}\right\}$

At first, correlation analyses employing the Pearson correlation coefficient $\left(r_{i j}\right)$ were conducted to test the significance, strength, and direction of the relationships between Austrian pine, Scots pine, and fir 3CNL log sales prices $\left(\mathrm{P}_{\mathrm{ik}}\right)$ of the Ankara RDF enterprises, along with the four variables in eqn. 1 related to the previous closest auction sales of neighboring FEs. Then, using significant correlations (confidence interval of at least 95\%) between the variables, the assumptions in Table 3 were derived.

In the first assumption (Table 3), when the duration between the dates of sale by auction of two FEs ( $\mathrm{FE}_{\mathrm{i}}$ and $\mathrm{FE}_{\mathrm{j}}$ ) increases (decreases), it is accepted that $\mathrm{FE}_{\mathrm{j}}$ competes with $\mathrm{FE}_{\mathrm{i}}$ for $\log$ type $\mathrm{k}$ if the sale price of the log type $\mathrm{k}$ of $\mathrm{FE}_{\mathrm{i}}$ moves higher (lower). 
Table 1 Log sales volumes of FEs in the study area.

\begin{tabular}{llrrr}
\hline \multirow{2}{*}{ Name of FEs } & Name of RDFs & \multicolumn{2}{c}{ Species of 3CNL Logs } \\
& & 44 & 1.653 & 0 \\
\hline Ankara & Ankara & 2.845 & 2.026 & 1.126 \\
Beypazari & Ankara & 1.651 & 9.856 & 5.817 \\
Camlidere & Ankara & 1.989 & 1.645 & 73 \\
Cankiri & Ankara & 1.482 & 1.345 & 6.265 \\
Cerkes & Ankara & 718 & 141 & 309 \\
Eskipazar & Ankara & 6.095 & 2.357 & 2.255 \\
Ilgaz & Ankara & 2.120 & 2.999 & 2.094 \\
Kizilcahamam & Ankara & 7.534 & 0 & 0 \\
Nallihan & Ankara & 1.473 & 1.751 & 0 \\
Catacik & Eskisehir & 8.542 & 1.180 & 0 \\
Mihaliccik & Eskisehir & 13.214 & 4.066 & 20.641 \\
Karabuk & Zonguldak & 12.265 & 230 & 21.264 \\
Yenice & Zonguldak & 434 & 11.094 & 28.017 \\
Gerede & Bolu & 6.546 & 0 & 0 \\
Goynuk & Bolu & 4.008 & 8.825 & 2.750 \\
Kibriscik & Bolu & 9.825 & 1.572 & 4.311 \\
Mengen & Bolu & 6.901 & 1.025 & 5.487 \\
Mudurnu & Bolu & 1.361 & 1.825 & 741 \\
Seben & Bolu & 6.242 & 2.179 & 5.665 \\
Arac & Kastamonu & 1.280 & 1.064 & 5.384 \\
Ihsangazi & Kastamonu & 5.501 & 4.821 & 5.725 \\
Kastamonu & Kastamonu & 5.150 & 3.697 & 2.715 \\
Tosya & Kastamonu & 2.181 & 638 & 0 \\
Corum & Amasya & 4.989 & 930 & 3.022 \\
Iskilip & Amasya & 2.531 & 131 & 893 \\
Samatlar & Amasya & & & 03 \\
\hline & & & & 0 \\
\hline
\end{tabular}

Table 2 Definitions of the variables in the log sales price model.

\begin{tabular}{|c|c|}
\hline Variables & Definitions \\
\hline $\mathrm{P}_{\mathrm{ik}}$ & $\begin{array}{l}\text { Sales price of a lot of log type k put on an auction sale at time t by a forest enterprise } i \text { of } \\
\text { the Ankara RDF }\left(\mathrm{P}_{\mathrm{i}} \text { Apine3CNL }\right. \\
\text { for Austrian pine 3CNL, } \mathrm{P}_{\mathrm{i} \_ \text {Spine3CNL }} \text { for Scots pine } 3 \mathrm{CNL} \text { and } \\
\left.\mathrm{P}_{\mathrm{i} \_ \text {Fir3CNL }} \text { for fir } 3 \mathrm{CNL}\right)\end{array}$ \\
\hline Numday $_{\mathrm{ij}}$ & $\begin{array}{l}\text { Day number between an auction sale of } \mathrm{FE}_{\mathrm{i}} \text { of the Ankara RDF and the closest previous auction } \\
\text { sale by another forest enterprise } \mathrm{j}\left(\mathrm{say}, \mathrm{FE}_{\mathrm{j}} \text { ), affiliated with Ankara or a neighboring RDF }\right.\end{array}$ \\
\hline Sameday $_{\mathrm{ij}}$ & Dummy variable, 1 if auction sales of $\mathrm{FE}_{\mathrm{i}}$ and $\mathrm{FE}_{\mathrm{j}}$ are on the same day, and 0 otherwise \\
\hline $\mathrm{Vol}_{\mathrm{j} 1}$ & $\begin{array}{l}\text { Sales volume of wood type } 1 \text { at the closest previous auction sale by } \mathrm{FE}_{\mathrm{j}} \text { before } \mathrm{FE}_{\mathrm{i}}\left(\mathrm{Vol}_{\mathrm{AR} \text { Apine3CTL }}\right. \\
\text { for volume of Austrian pine CTL log, } \mathrm{Vol}_{\mathrm{MH} \_\mathrm{Apine} 3 \mathrm{CSL}} \text { for volume of Austrian pine CSL log) }\end{array}$ \\
\hline$P_{j 1}$ & $\begin{array}{l}\text { Mean sales price of wood type } 1 \text { at the closest previous auction sale by } \mathrm{FE}_{\mathrm{j}} \text { before } \\
\mathrm{FE}_{\mathrm{i}}\left(\mathrm{P}_{\mathrm{GR} \text { Fir3CNL }} \text { for price of fir } 3 \mathrm{CNL} \log , \mathrm{P}_{\mathrm{KR} \text { Fir }} \text { for price of fir log, } \mathrm{P}_{\mathrm{KR} \text { Fir3CNL }}\right. \\
\text { for price of fir 3CNL log, } \mathrm{P}_{\mathrm{TS} \text { Pine }} \text { for price of Pine log in sales price functions) }\end{array}$ \\
\hline Pres $_{\mathrm{ik}}$ & Reserve price of the sales lot for log type $\mathrm{k}$ of $\mathrm{FE}_{\mathrm{i}}$ at an auction sale \\
\hline
\end{tabular}


On the other hand, according to the second assumption, if the sales price of log type $\mathrm{k}$ increases when the duration between the auction sale dates of two FEs is reduced, it is accepted that these two FEs might be in "cooperation" in the market. According to the third assumption, if the correlation coefficient between the prices of log type $\mathrm{k}$ in the $\mathrm{FE}_{\mathrm{i}}$ and the condition of $\mathrm{FE}_{\mathrm{i}}$ holding an auction sale on the same day as $\mathrm{FE}_{\mathrm{j}}$ is negative - in other words, if $\mathrm{P}_{\mathrm{ik}}$ decreases when the FEs ( $i$ and $j$ ) conduct auction sales on the same day, then the two FEs are competitors for log type $\mathrm{k}$. By contrast, if the prices of log type $\mathrm{k}$ increase, despite the sales by auction being held on the same day, it is possible with the fourth assumption that cooperation has appeared between the two FEs in terms of log type $\mathrm{k}$. These assumptions required that the correlation coefficient be at least moderate according to Hinkle's (2003) classifications ( $r$ > 0.50 or $\mathrm{r}<-0,50)$ and the neighboring FEs that are competing or cooperating with the Ankara FEs that meet each assumption were determined.

Even though the length of time between sales by auction are fixed, the relationship between the sales volumes $\left(\mathrm{Vol}_{\mathrm{j} 1}\right)$ or sales prices of the wood types $\left(\mathrm{P}_{\mathrm{jl}}\right)$ in the auction sale of FEj and the log type $\mathrm{k}$ sales price $\left(\mathrm{P}_{\mathrm{ik}}\right)$ of $\mathrm{FE}_{\mathrm{i}}$ can be defined as an indicator of the competitive or cooperative relationship between the FEs. When the fifth assumption is applied, if the sales price of log type $\mathrm{k}$ at the auction of $\mathrm{FE}_{\mathrm{i}}$ of the Ankara RDF exhibit an inverse relationship with the total sales volume of wood type 1 in the previous auction of the neighboring $\mathrm{FE}_{\mathrm{i}}$, the log type $\mathrm{k}$ of the $\mathrm{FE}_{\mathrm{i}}$ and the wood type $\mathrm{k}$ of the $\mathrm{FE}_{\mathrm{j}}$ are considered to be rival commodities.

By the last assumption, if the average price $\left(\mathrm{P}_{\mathrm{jj}}\right)$ of a wood type 1 included in the auction sales of the neighboring $\mathrm{FE}_{\mathrm{j}}$ changes in the same direction as the sales price $\left(\mathrm{P}_{\mathrm{ik}}\right)$ of a log type $\mathrm{k}$ in the next sale of the $\mathrm{FE}_{\mathrm{i}}$, this is considered an indicator of a complementary relationship between the two goods. Only high and very high correlations according to Hinkle's (2003) classifications (r $>0.70$ or $\mathrm{r}<-0,70$ ) were considered in these assumptions due to the high number of total wood types, and the number of rival and complementary goods of the neighboring FEs was also determined.

Then, the model in eqn. 1 was used to determine the magnitude of the effects of neighborhood relations on the sales prices of Austrian pine, Scots pine, and fir logs in the Ankara RDF enterprises. Only one price function for each log type was predicted for one FE of the Ankara RDF by means of multiple regression analyses. FEs with moderate levels of production for each log type in the Ankara $\mathrm{RDF}$ were preferred during the selection of the FE, whose sales price function would be estimated. In this regard, the sales price functions of the Austrian pine 3CNL log $\left(\mathrm{P}_{\mathrm{BE}}\right.$ Apine3CNL$)$ in the Beypazari FE, the Scots pine $3 C N L \log \left(\mathrm{P}_{\text {IL Spine3CNL }}\right)$ in the Ilgaz FE, and the Fir $3 \mathrm{CNL} \log \left(\mathrm{P}_{\mathrm{CM} \mathrm{Fir3CNL}}\right)$ in the Camlidere FE were derived. A semilogarithmic function type (eqn. 2) was preferred in the multiple regression analyses, as it derives more significant functions and its marginal effects can be easily calculated.

$$
\begin{aligned}
\ln P_{\mathrm{ik}} & =\alpha+\beta_{\text {numday }} \text { Numday }_{\mathrm{ij}}+\beta_{\text {sameday }} \text { Sameday }_{\mathrm{ij}}+ \\
& +\beta_{\mathrm{vo}} \text { Vol }_{\mathrm{j} 1}+\beta_{\mathrm{p}} \mathrm{P}_{\mathrm{j} 1}+\beta_{\text {pres }} \text { Pres }_{\mathrm{ik}}
\end{aligned}
$$

\begin{tabular}{|c|c|c|}
\hline No & Condition & Competition/cooperation \\
\hline 1 & $\mathrm{r}_{\mathrm{ij}}\left(\mathrm{P}_{\mathrm{ik}}\right.$, Numday $\left._{\mathrm{ij}}\right)>0.50$ & Competition between $\mathrm{FE}_{\mathrm{i}}$ and $\mathrm{FE}_{\mathrm{j}}$ for log type $\mathrm{k}$ \\
\hline 2 & $\mathrm{r}_{\mathrm{ij}}\left(\mathrm{P}_{\mathrm{ik}}\right.$, Numday $\left._{\mathrm{ij}}\right)<-0.50$ & Cooperation between $\mathrm{FE}_{\mathrm{i}}$ and $\mathrm{FE}_{\mathrm{j}}$ for log type $\mathrm{k}$ \\
\hline 3 & $\mathrm{r}_{\mathrm{ij}}\left(\mathrm{P}_{\mathrm{ik}}\right.$ Sameday $\left._{\mathrm{ij}}\right)<-0.50$ & Competition between $\mathrm{FE}_{\mathrm{i}}$ and $\mathrm{FE}_{\mathrm{j}}$ for log type $\mathrm{k}$ \\
\hline 4 & $\mathrm{r}_{\mathrm{ij}}\left(\mathrm{P}_{\mathrm{ik}}\right.$, Sameday $\left._{\mathrm{ij}}\right)>0.50$ & Cooperation between $\mathrm{FE}_{\mathrm{i}}$ and $\mathrm{FE}_{\mathrm{j}}$ for log type $\mathrm{k}$ \\
\hline 5 & $\mathrm{r}_{\mathrm{ij}}\left(\mathrm{P}_{\mathrm{ik}}, \mathrm{Vol}_{\mathrm{j} 1}\right)<-0.70$ & $\begin{array}{l}\mathrm{k} \text { and } \mathrm{l} \text { are rival goods (Competition between } \mathrm{FE}_{\mathrm{i}} \text { and } \mathrm{FE}_{\mathrm{j}} \text { for two } \\
\text { wood types) }\end{array}$ \\
\hline 6 & $\mathrm{r}_{\mathrm{ij}}\left(\mathrm{P}_{\mathrm{ik}}, \mathrm{P}_{\mathrm{j} 1}\right)>0.70$ & $\begin{array}{l}\mathrm{k} \text { and } 1 \text { are complementary goods (Cooperation between } \mathrm{FE}_{\mathrm{i}} \text { and } \\
\mathrm{FE}_{\mathrm{j}} \text { for two wood types) }\end{array}$ \\
\hline
\end{tabular}

Table 3 Assumptions for recognizing competition and cooperation between forest enterprises. 
The reserve price $\left(\operatorname{Pres}_{\mathrm{ik}}\right.$ ), also known as the upset price or appraised value (Athey et al. 2002, Chakravarti et al. 2002, Saphores et al. 2016, Öztürk et al. 2019), was regarded in the model as a starting price offer in the auction. Other variables in the model are determinants of the share remaining from the reserve price within the sales price. Moreover, some variables were neglected in the sales price model to enable a focus on the competition and cooperation problem addressed in the study: these include the attributes of the log types sold by $\mathrm{FE}_{\mathrm{i}}$, the volumes of other wood types, the competition between the bidders, volume and quantity of stumpage sales, imported wood products in the market, volumes and prices of other substitute goods, derived demand, and the macroeconomic situation.

The partial derivative of the price function (eqn. 2) with respect to any independent variable reveals the marginal effect of the variable upon the price. Thus, the marginal effect of any variablefor example, the length of time after an auction sale held by the neighboring $\mathrm{FE}_{\mathrm{j}}$ on the sales price of the log type $\mathrm{k}$ in $\mathrm{FE}_{\mathrm{i}}$ of the Ankara $\mathrm{RDF}$-was calculated as follows (eqn. 3):

$$
\frac{\partial \mathrm{P}_{\mathrm{ik}}}{\partial \beta_{\text {numday }}}=\beta_{\text {numday }} \mathrm{P}_{\mathrm{ik}}
$$

Data for all analyses were obtained from the auction sheets containing the sales results of the relevant Ankara RDF enterprises for 3502 log lots sales included in the 104 sales by auction conducted in the Ankara RDF between 2017 and 2018. The datasets of the neighboring FEs were obtained from the records of 451 sales by auction conducted by internal and external neighboring FEs between 2016 and 2018, as well as the Forest Information System of the GDF, as it was necessary to obtain previous auction sales data. The sales prices of all wood types were converted into real prices as of July 2019, with reference to the Turkish Statistical Institute (TurkStat) Producer Price Index $(2003=100)$ and were employed in the analyses (TurkStat 2019). SPSS 21.0 and MS Excel were used for all statistical analyses.

\section{Results}

\section{Log prices and duration between FEs' auctions}

Regarding the number of days between the most recent sales $\left(\right.$ Numday $_{\mathrm{ij}}$ ), the neighboring FEs that exhibited upper-moderate correlations with the prices of Austrian pine $\log \left(\mathrm{P}_{\mathrm{i} \text { Apine3CNL }}\right)$ in the sales by auction of FEs in the Ankara RDF are presented in Figure 2. In the part where the correlation coefficients were positive, resulted the FEs were rival to the Ankara RDF enterprises for Austrian pine $\log$ prices in terms of the variable Numday $_{\mathrm{ij}}$; by contrast, this variable revealed an effect of "cooperation" in the parts where the correlation coefficients were negative. Figure 2 shows the cooperative and rival enterprises of each $\mathrm{FE}$ in the Ankara RDF, as well as border neighborship. As an example, the first column of Figure 2 shows that while the Beypazari FE had competitive relationships with the Arac, Mengen, Samatlar, and Nallihan FEs, it had cooperative relationships with the Mihaliccik, Eskipazar, and Kibriscik FEs, even though Beypazari does not border the Nallihan and Kibriscik FEs.

By considering the Numday $_{\mathrm{ij}}$ variable, 38 competitive or cooperative relationships among the FEs were determined for the Scots pine log sales prices (Figure 3). When the log species changed from the Austrian pine (Figure 2 ) to the Scots pine (Figure 3), the total number of competitive and cooperative relationships among the FEs did not change. However, the number of cooperative enterprises increased in the Scots pine logs, while the number of enterprises competing decreased.

Figure 4 plots the neighboring FEs exhibiting the least moderate correlations between the fir log prices $\left(\mathrm{P}_{\mathrm{i} \text { Fir3CNL }}\right)$ at auction sales in the Ankara RDF FEs and the variable Numday ${ }_{\mathrm{ij}}$. It is determined that the number of competition and cooperation relationships among the FEs for the fir log is less than for the Austrian pine and the Scots pine. 


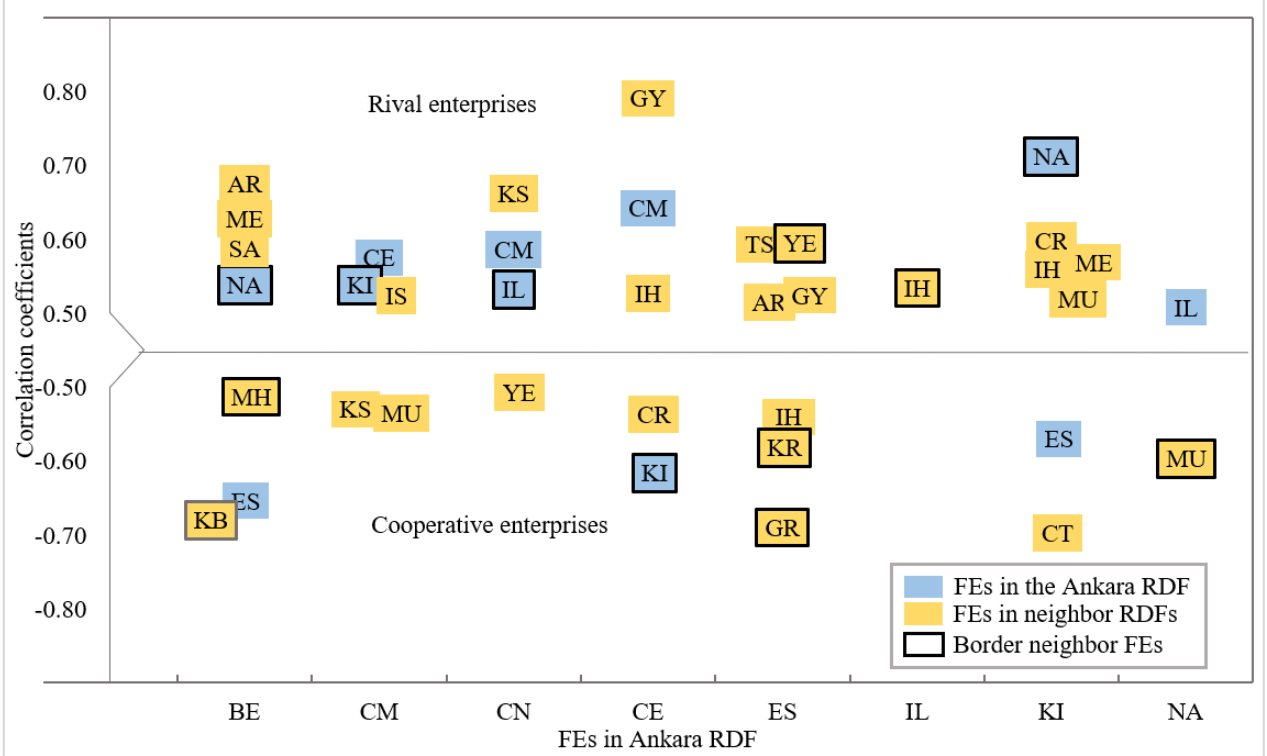

Figure 2 Correlations for the FEs between Austrian pine log prices and the time between sales dates.

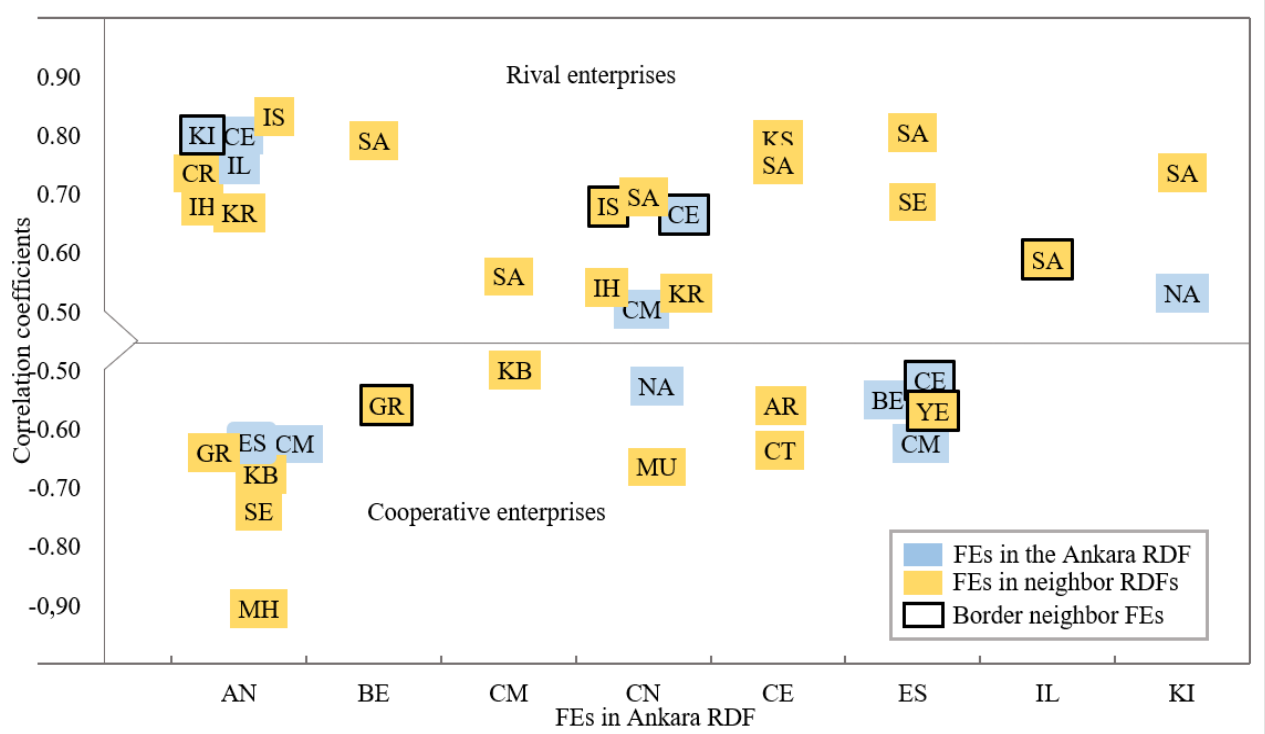

Figure 3 The correlations of the FEs between the Scots pine log prices and the duration of sales dates.

Log prices and FEs' same day auctions

Figure 5 plots FEs that have at least a moderate correlation between $\log$ prices $\left(\mathrm{P}_{\mathrm{ik}}\right)$ in sales by auctions in regards to FEs in the Ankara RDF and the dummy variable Sameday ${ }_{i j}$ on the presence of sales realized by other FEs on the same day in 130 the study area. Contrary to Figures 2, 3, and 4, in the upper part of Figure 5 where the correlation coefficients were positive, there were FEs in cooperation because they had auctions on the same day as the FEs of the Ankara RDF, thus increasing the prices, while there were rival FEs with reversedirection changes in Sameday ${ }_{\mathrm{ij}}$ in the bottom part. 


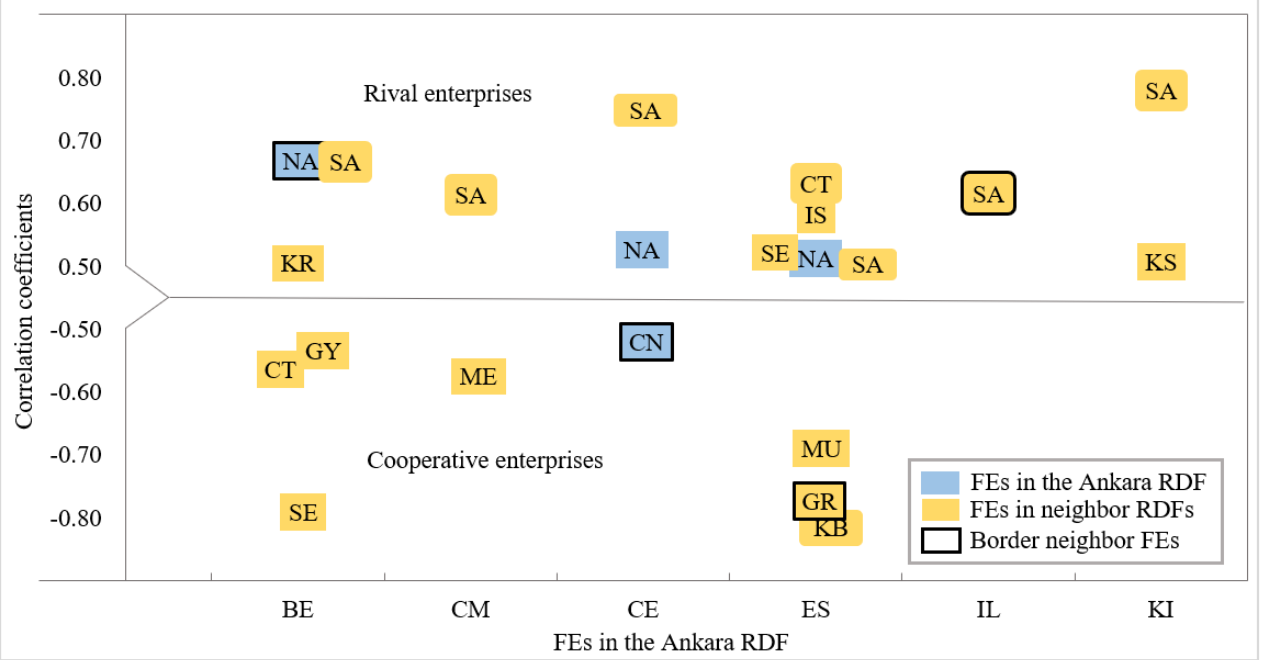

Figure 4 Correlations of the FEs between the fir log prices and the duration of sales dates.

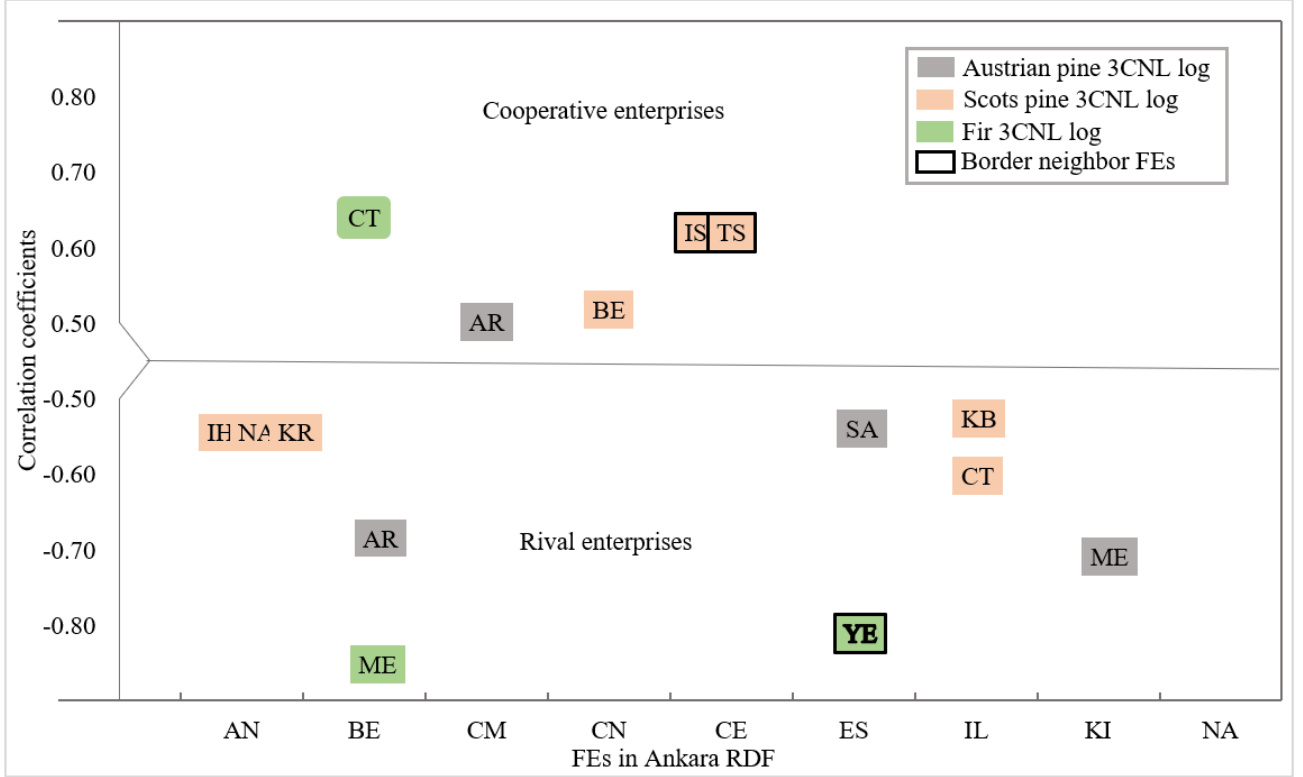

Figure 5 The relationship between the prices in FEs when auctions are held on the same day.

Price-price and volume-price correlations between FES

Figure 6 summarizes the results of correlational analyses conducted between the Austrian pine, Scots pine, and fir log prices of FEs in the Ankara RDF and sales volumes and prices of the other wood types in previous auctions held in neighboring FEs. The number of "rival" wood types in neighboring FEs with a high negative correlation between sales prices and volumes of three types of logs in FEs in the Ankara RDF is presented under the axis in Figure 6, while the number of "complementary" wood types with high positive relationships with the sales prices of Austrian pine, Scotch pine, and fir logs can be seen in the upper part. 


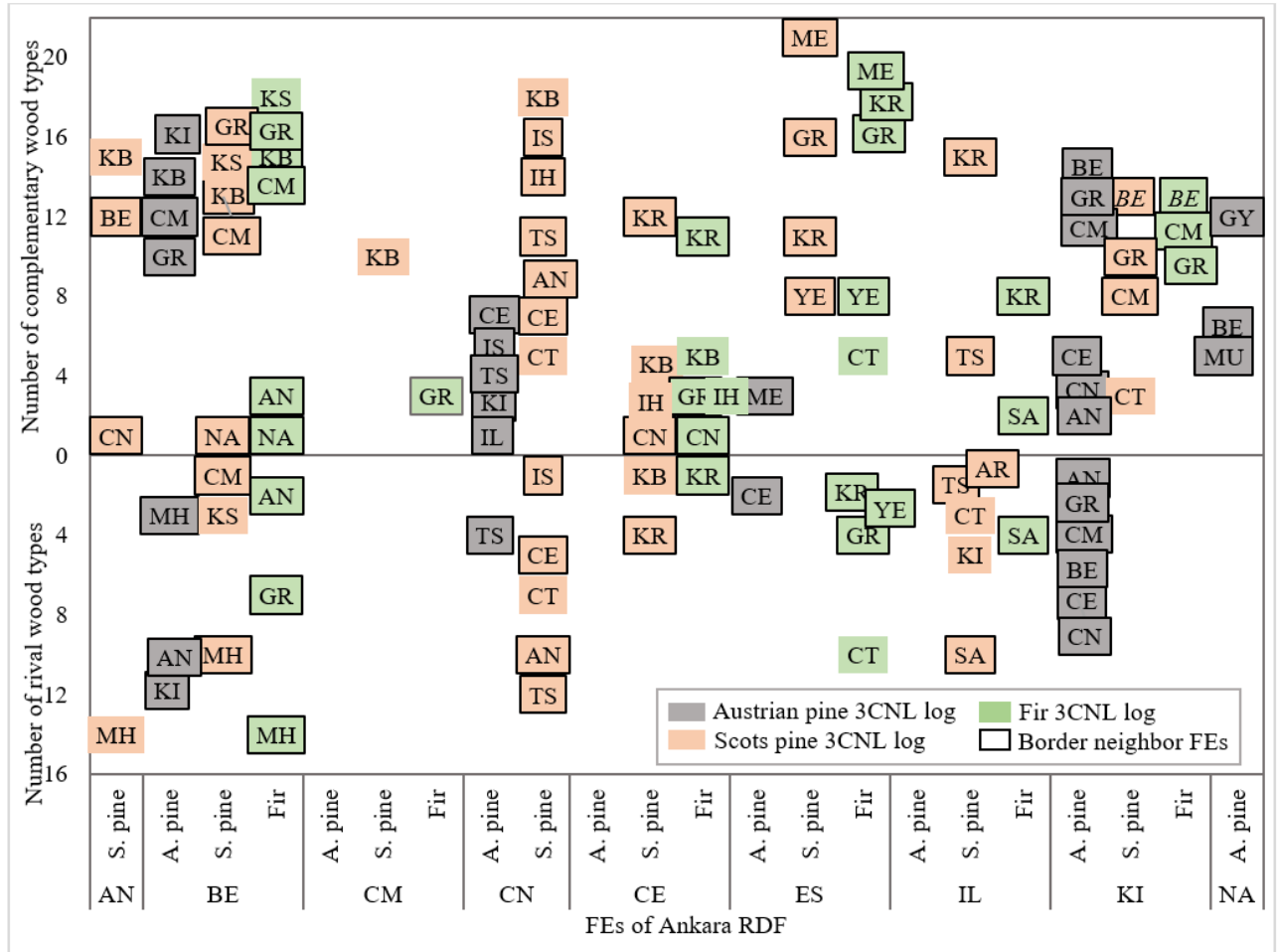

Figure 6 The numbers of rival and complementary wood types of neighboring FEs.

\section{Sales price functions}

All three sales price functions (Table 4) are found to be highly significant $(p<0.001)$. While the sales price functions of Austrian pine $\log$ in the Beypazari FE and of Scots pine logs in the Ilgaz FE explain $87.2 \%$ and, respectively, $80.1 \%$ of the variation in sales prices, the fir price function of the Camlidere FE explains $71.3 \%$ of the variation in sales prices of the fir $\log$. The most of the variables in all sales price functions are statistically significant $(\mathrm{p}<0.01)$. The variables Numday $_{\mathrm{ME}}$ and Numday $_{\mathrm{NA}}$ were related to the duration after the auctions of the Mengen and Nallihan FEs and had significant positive effects on the Austrian pine log prices of the Beypazari FE (Table 4). These findings resemble the results of the correlation analysis in Figure 2. Similarly, the variable of duration after the auctions of the Samatlar FE (Numday ${ }_{\mathrm{SA}}$ ) had a competitive effect on the Scots pine log price function in the Ilgaz FE and the fir log price function in the Camlidere FE. These findings fit well with the correlation results in Figure 3 and Figure 4. Unlike Austrian log prices in the Beypazari FE, the duration after the auction of the Mengen FE ( Numday $_{\mathrm{ME}}$ ) had a negative (i.e., cooperative) effect on fir log prices in the Camlidere FE, similar to the results shown in Figure 4. Moreover, the negative effects of making an auction on the same day as the Arac FE $\left(\right.$ Sameday $\left._{A R}\right)$ on Austrian pine log price functions in the Beypazari FE, along with the negative effects of making an auction on the same day as the Kibriscik FE $\left(\right.$ Sameday $_{\mathrm{KB}}$ ) on the Scots pine log sales price functions in the Ilgaz FE are in line with the competitive effect shown in Figure 5.

Furthermore, the competitive effects of the sales volumes of Austrian pine third-class short length $\log$ in the Mihaliccik FE and Austrian 
pine third-class long-length log in the Arac FE ( $\mathrm{VOl}_{\mathrm{MH} \text { Apine3CSL }}$ and $\mathrm{Vol}_{\mathrm{AR} \text { Apine3CTL }}$, respectively) were observed in the Austrian pine and the Scots pine log sales price functions (Table 4). In addition, the complementary goods effects of fir log prices in the Gerede FE, fir log and fir
$3 \mathrm{CNL} \log$ sales prices in the Karabuk FE, and pine log sales prices in the Tosya $F E\left(\mathrm{P}_{\mathrm{GR}}\right.$ Fir3CNL , $\mathrm{P}_{\text {KR_Fir }}, \mathrm{P}_{\text {KR Fir3CNL }}, \mathrm{P}_{\text {TS Pine }}$, respectively) were determined in the sales price functions in Table 4. All of these effects are consistent with the results shown in Figure 6.

Table 4 Sales price functions.

\begin{tabular}{|c|c|c|c|c|c|c|}
\hline \multirow{2}{*}{ Variables } & \multicolumn{2}{|c|}{ Apine3CNL of Beypazari FE } & \multicolumn{2}{|c|}{ Spine3CNL of Ilgaz FE } & \multicolumn{2}{|c|}{ Fir3CNL of Camlidere FE } \\
\hline & $\beta$ & t-test & $\beta$ & t-test & $\boldsymbol{\beta}$ & t-test \\
\hline Constant & $5.0495 * * *$ & 27.195 & $5.0391 * * *$ & 31.327 & $5.4468 * * *$ & 99.325 \\
\hline Numday $_{\mathrm{ME}}$ & $0.0028 * * *$ & 4.627 & & & $-0.0010 * *$ & -2.532 \\
\hline Numday $_{\mathrm{NA}}$ & $0.0017 * * *$ & 5.707 & & & & \\
\hline Numday $_{\text {SA }}$ & & & $0.0005^{* * *}$ & 4.807 & $0.0002 * *$ & 2.276 \\
\hline Sameday $_{\mathrm{AR}}$ & $-0.0909 * * *$ & -4.391 & & & & \\
\hline Sameday $_{\text {Кв }}$ & & & $-0.1082 * * *$ & -4.115 & & \\
\hline $\mathrm{Vol}_{\text {AR_Apine3CTL }}$ & & & $-0.0016^{* * *}$ & -2.870 & & \\
\hline $\mathrm{Vol}_{\mathrm{MH} \text { Apine3CSL }}$ & $-0.0003 * * *$ & -4.976 & & & & \\
\hline $\mathrm{P}_{\mathrm{GR} \text { Fir3CNL }}$ & & & & & $0.0004 * * *$ & 3.447 \\
\hline$P_{K R \text { Fir }}$ & & & $0.0008 * * *$ & 4.358 & & \\
\hline $\mathrm{P}_{\mathrm{KR} \text { Fir3CNL }}$ & & & & & $0.0002 *$ & 1.683 \\
\hline $\mathrm{P}_{\mathrm{TS}}$ Pine & & & $0.0005 * *$ & 2.391 & & \\
\hline Pres & $0.0030 * * *$ & 6.286 & $0.0012 * * *$ & 3.482 & $0.0014^{* * *}$ & 8.317 \\
\hline $\mathrm{n}$ & 168 & & 176 & & 258 & \\
\hline F-test & $227.5470 * * *$ & & $118.5808^{* * *}$ & & $128.5505^{* * *}$ & \\
\hline $\mathrm{R}^{2}$ & 0.8754 & & 0.8081 & & 0.7184 & \\
\hline $\mathrm{R}^{2}$ adj & 0.8715 & & 0.8012 & & 0.7128 & \\
\hline
\end{tabular}

Notes: $* \mathrm{p}<0.1 ; * * \mathrm{p}<0.05 ; * * * \mathrm{p}<0.01$.

Table 5 Marginal effects of variables on sales prices.

\begin{tabular}{|c|c|c|c|c|c|c|}
\hline \multirow{2}{*}{ Variables } & \multicolumn{2}{|c|}{ Beypazari - $\mathbf{P}_{\mathrm{BE} \_ \text {Apine3CNL }}$} & \multicolumn{2}{|c|}{ Ilgaz $-P_{I L \_S p i n e 3 C N L}$} & \multicolumn{2}{|c|}{ Camlidere $-\mathbf{P}_{\mathrm{CM} \_ \text {Fir3CNL }}$} \\
\hline & Mean & Marginal effect (t) & Mean & Marginal effect (\$) & Mean & Marginal effect (‡) \\
\hline Numday $_{\mathrm{ME}}$ & 12.89 & 1.34 & & & 21.21 & -0.53 \\
\hline Numday $_{\mathrm{NA}}$ & 26.19 & 0.83 & & & & \\
\hline Numday $_{S A}$ & & & 117.61 & 0.28 & 132.96 & 0.10 \\
\hline Sameday $_{A R}$ & 0.23 & -43.57 & & & & \\
\hline Sameday $_{K B}$ & & & 0.13 & -58.00 & & \\
\hline $\mathrm{Vol}_{\text {AR_Apine3CTL }}$ & & & 11.44 & -0.86 & & \\
\hline $\mathrm{Vol}_{\text {MH_Apine3CSL }}$ & 278.86 & -0.14 & & & & \\
\hline $\mathrm{P}_{\mathrm{GR} \_ \text {Fir3CNL }}$ & & & & & 546.62 & 0.20 \\
\hline$P_{\text {KR_Fir }}$ & & & 580.61 & 0.44 & & \\
\hline $\mathrm{P}_{\text {KR_Fir3CNL }}$ & & & & & 572.36 & 0.13 \\
\hline $\mathrm{P}_{\mathrm{TS} \text { Pine }}$ & & & 512.20 & 0.25 & & \\
\hline
\end{tabular}


The variable of Numday $_{\mathrm{ME}}$ (Table 5) shows that each day that passes after the date of sale in the Mengen FE increases the Austrian pine log price by $1.34 \mathrm{TL} / \mathrm{m}^{3}$ and decreases the fir $\log$ sales price in the Camlidere FE by $0.53 \mathrm{TL} / \mathrm{m}^{3}$. If the auction is held on the same day as the Arac $\mathrm{FE}$, the Austrian pine log price in the Beypazari FE decreases by $43.57 \mathrm{TL} / \mathrm{m}^{3}$; moreover, if an auction is held on the same day as the Kibriscik $\mathrm{FE}$, the Scots pine log price in the Beypazari FE decreases by $58 \mathrm{TL} / \mathrm{m}^{3}$. On the other hand, an increase of $1 \mathrm{~m}^{3}$ in the sales volume of Austrian pine third-class long-length $\log$ in an auction in the Arac FE causes a decrease of $0.86 \mathrm{TL} /$ $\mathrm{m}^{3}$ in Scots pine third-class long-length log sales prices in the Ilgaz FE. In addition, an average of $1 \mathrm{TL} / \mathrm{m}^{3}$ increase in sales price of fir logs in the auctions held in the Gerede FE causes a sales price increase of $0.20 \mathrm{TL}$ per $\mathrm{m}^{3}$ in fir $3 \mathrm{CNL}$ logs in the Camlidere FE.

\section{Discussion}

These study results are similar to the competition findings in the Turkish literature (Ok 1997a, Daşdemir 2001, Daşdemir 2008); however, our findings also prove that there might exist cooperation as well as competition. Our study found that it is neither sufficient nor necessary for FEs to be borderline neighbors for competition or cooperation to occur. In contrast to Sekot's (1998) suggestion that competition between FEs is relatively low, we found that 60 of 98 relationships between nine FEs in the Ankara RDF and 26 neighboring FEs for three log types were competitive.

The competitive and cooperative relationships determined to exist between the FEs based on the variables of Numday $_{i j}$ and Sameday $_{\mathrm{ij}}$, which were associated with the timely relationship of sales, were consistent. As the duration between the auctions shortens, or in the context of sales made on the same day, for example, the Beypazari FE becomes the "rival" of the Arac FE in terms of Austrian pine log sales, while the Kizilcahamam FE becomes the "rival" of the Mengen FE in terms of the same log type, and the Ankara FE becomes the "rival" of both the Karabuk and Ihsangazi FEs in terms of Scots pine log sales. The Beypazari FE was found to be in cooperation with the Catacik FE in terms of two variables in fir log sales.

The scarcity of significant relationships between auctions being held on the same day within neighboring FEs and sales prices is likely the consequence of measures adopted and implemented by the GDF within the RDF. Due to the GDF's policy of preventing sales being held on the same day by controlling sales held by the FEs within the same RDFs, a low number of competitive relationships (two correlations) was detected within the Ankara RDF, while more correlations (13) were obtained from other RDFs. This proves that the scale of the measures taken by the GDF based on Regional Directorates is insufficient, and that interregional coordination is needed to determine the dates of sales. On the other hand, the findings that one-third of significant correlations were positive and that correlations change based on log type revealed that while some FEs may experience revenue loss for each log type if sales are held on the same day, other FEs may gain a price advantage. This information shows that the measures taken by the GDF to prevent absolute competition are not sufficient and that sales programs should be developed to support cooperation in some cases.

The positive high correlation found in this study between the sales prices of three types of $\log$ in the FEs of the Ankara RDF and the prices of the wood types of neighboring FEs in previous auctions is consistent with the results of Daşdemir (2001, 2008). We found that the number of wood types with positive high correlation can exceed one, and that these wood types are defined as complementary goods. In addition, rival goods were determined using negative high correlations with the sales volumes of wood types in neighboring FEs. The numbers of rival and complementary 
wood types in neighboring FEs change among FEs, regardless of whether or not they are bordering neighbors. Additionally, it is significant that some FEs compete with other FEs for one wood type while cooperating with them for another wood product. This finding underscores the fact that interactions between FEs are far more complex than suggested by the findings of the studies discussed above.

It is possible to use the results of the marginal effect analysis to discuss the sensitivity of the independent variables. In this context, considering the Austrian pine sales price function and marginal effects in Table 5, when the mean number of days between the dates of sales held by the Beypazari and Mengen FEs (12.89) is increased by 10, the Austrian pine log price in the Beypazari FE might increase by $13.4 \mathrm{TL} / \mathrm{m}^{3}$. By contrast, when the mean duration between the dates of sales held by the Beypazari and Nallihan FEs is decreased from 26 days to 16 , it is predicted that the Austrian pine sales price in Beypazari will decrease by $8.3 \mathrm{TL} / \mathrm{m}^{3}$. We suggest that these \pm 10 -day interventions on the duration between the dates of sales held by the Beypazari FE and its rival FEs in terms of Austrian pine sales will cause an increase of $2.8 \%$ and a decrease of $1.7 \%$, respectively, in the sale price.

Similarly, this study found that holding an auction on the same day as the Arac FE decreased Austrian pine log prices in the Beypazari FE by $9.1 \%$; this finding must be interpreted in the context of the FE having lost $43.570 \mathrm{TL}$ in revenue on sales of $1.000 \mathrm{~m} 3$. The fact that $23 \%$ of the auctions in the Beypazari FE were held on the same day as the Arac FE during the studied period is important to fully evaluate the size of the resulting revenue loss. Moreover, Ankara RDF marketing unit officials and the Beypazari FE must be aware that when Austrian pine log sales volume increases by $100 \mathrm{~m}^{3}$ in the Mihaliccik FE, it decreases Austrian pine log prices by $14 \mathrm{TL} /$ $\mathrm{m}^{3}$. In other words, it must be noted that an additional revenue of 372.53 TL gained from 1 $\mathrm{m}^{3}$ of Austrian pine third-class short-length log sales in the Mihaliccik FE causes a decrease of $0.14 \mathrm{TL} / \mathrm{m}^{3}$ in Austrian pine log sales in the Beypazari FE, and thus creates an opportunity cost for the GDF.

The marginal effects of the variables of Numday $_{\mathrm{SA}}$, Sameday ${ }_{\mathrm{KB}}$, and $\mathrm{Vol}_{\mathrm{AR} \text { _Apine3CTL }}$ on Scots pine log prices can be investigated using the Scots pine log sales price function of the Ilgaz FE. Moreover, as proof of cooperation and the presence of complementary goods between FEs, the increase of $10 \mathrm{TL} / \mathrm{m}^{3}$ in average sales prices of fir log in the auctions of the Karabuk FE, and of Pine $\log$ in the auctions of the Tosya FE, caused an increase in Scots pine log sales prices of $4.4 \mathrm{TL} / \mathrm{m}^{3}$ and, respectively, $2.5 \mathrm{TL} / \mathrm{m}^{3}$ in the Ilgaz FE.

The fir $\log$ sales price function in the Camlidere FE makes a significant contribution in terms of the marginal effects of the variables. While increased time after the auctions of the Mengen FE created a competitive effect on the Austrian pine log sales prices in the Beypazari FE, as mentioned above, it has had, also, a cooperative effect on the fir log sales price of the Camlidere FE. When the mean duration of 21 days between the sales of two FEs is decreased by 10 days, the fir log sales prices in the Camlidere FE increase by $5.3 \mathrm{TL} / \mathrm{m}^{3}$. This is proof that the effects of the duration between sales times of neighboring FEs differ across different FEs and different wood types in terms of both the direction and size of the competition and cooperation. These evaluations reveal that producing a statistically significant price function will facilitate understanding what variables in the market should be followed as well what marketing decisions should be taken, by producing predictions for different possible situations.

The present study's examination of the width of the product range covered by the number of FEs required the calculation and interpretation of a large number of correlation coefficients, raising the question of whether or not this was proportional to its statistical explanatory 
power. When the regression approach is used to analyze cooperation and competition between FEs, it is necessary to derive numerous models, incorporating many variables that are specific to each product type and can show either competition or cooperation relationship. Although regression outcomes that support the correlation results were obtained in this study, it is a fact that more practical methods capable of showing the competition and cooperation experienced by many FEs for many products are needed.

\section{Conclusions}

Today's enterprises have to become proactive firms that can develop positive attitudes towards possible situations. The results of the study prove that the intuitive decisions of the directors of the state FEs may not manage successfully the complex cooperative and competitive relationships among FEs under the same holding. Sales price functions should be produced and their validity tested to make predictions with up-to-date equations. The study results show that state FEs, which are related due to the presence of common customers and can be understood to operate in the same market, regardless of whether they are borderline neighbors affiliated under the same management, can establish competitive or cooperative relationships with different FEs for three different types of products. It is unknown whether the identified competitive and cooperative relationships obtained with the data from 2017-2018 years are valid in the future. The relationships may be changed by other variables in time. Therefore, instead of producing more raw wood materials, forest managers could improve capacity on the management of cooperative and competitive relations among FEs to create more financial resources for sustainable forest management. The state FEs affiliated to the same general directorate, such as the GDF, should develop a marketing program under the principle of "less competition and more cooperation" with other
FEs, not only border neighbors, but also all related FEs, regarding specific products. The study results show that the competitive and cooperative relationships between FEs should be analyzed on a product basis.

The GDF has organized sales in the scale of FEs, and attempted to program the sales of FEs affiliated to the same RDF. According to the results of this study, it is necessary to create "FE competition and cooperation maps" by determining the borders of product interactions between FEs. The GDF has programmed the sales of FEs within the borders of the regional directorate and transitioned to electronic sales. However, the next necessary step is to create a "marketing organization" that reduces the conflict between FEs competing on upon the same "product basis" at the country scale and provides "cooperation" between FEs in order to help each other.

A range of innovations should be considered. In contrast to traditional marketing applications, a cooperative FE may sell a wood type produced by one partner FE and collect payments on behalf of it. Moreover, in terms of alternative marketing strategies, organizing "product-specific" auction sales at the country or region scale, as well as determining the price in the same sale but delivering and collecting payments by each FE should be considered a means of creating more financial resources for sustainable forest management without increasing the level of production. Instead of many local auctions where one FE producing the same type of wood raw material competes in price with another FE or FEs, the arrangement of joint online open sales by the GDF for particularly valuable wood types may provide higher financial resources to all FEs. It will be an innovative marketing approach for GDF to put the product of different FE's in a joint online auction.

Forest managers should not fall into the trap of thinking that the research results are important only for state FEs. Private and community forest owners who have similar 
customers and make raw wood sales also need sustainable financial resources for sustainable forest management. Although it is not very common in Turkey, small-sized forest owners, in particular, should be supported with joint marketing programs that provide cooperation and protect them from the revenue-decreasing effects of competition. These programs should be considered a means of encouraging forest owners to adopt an approach in which they consider generating their own resources by more effectively "marketing" of what they produce rather than compelling them to acquire sustainable forest management resources through other financial support tools (such as taxes, subsidies, and incentives) or by intervening in the market mechanism. If a state FE in Turkey or a private forest owner somewhere in the world can create more financial resources by more effectively marketing the raw wood material it produces, this will enable them to develop a more sustainable approach and capacity than forests based on funding from grants and taxes.

\section{Acknowledgements}

This article was created from the database of a research project numbered 23.5303/20162018-2019 funded by the Central Anatolia Forestry Research Institute, which is an R\&D unit of the GDF. Authors also thank an anonymous reviewer whose suggestions improved significantly our manuscript.

\section{References}

Athey S., Cramton P., Ingraham A., 2002. Auction-based timber pricing and complementary market reforms in British Columbia. Market Design Inc. and Criterion Auctions, Bethesda, Maryland.

Belloc F., 2014. Innovation in state-owned enterprises: reconsidering the conventional wisdom. Journal of Economic Issues 48: 821-848. https://doi.org/10.2753/ JEI0021-3624480311

Coillte, 2020. Coillte Annual Report 2019. https://www. coillte.ie/media/2020/05/Coillte-Annual-Report-2019. pdf

Chakravarti D., Greenleaf E., Sinha A., Cheema A., Cox J.C., Friedman D., 2002. Auctions: Research opportunities in marketing. Marketing Letters 13: 281296. https://doi.org/10.1023/A:1020399513113

Daşdemir İ., 2001. Bartın ve Yenice orman işletmelerinde açık artırmalı göknar tomruk satışını etkileyen faktörler [The factors affecting the price of fir timber sale by auctions in Bartin and Yenice forest enterprises]. Bartın Journal of the Faculty of Forestry 3: 118-136. https:// dergipark.org.tr/tr/pub/barofd/issue/3411/46914

Daşdemir İ., 2008. Açık artırmalı kayın tomruk satış fiyatını etkileyen faktörler [Factors affecting the price of beech timber sale by auctions in Turkey]. Bartın Journal of the Faculty of Forestry 10: 1-12. https:// dergipark.org.tr/tr/pub/barofd/issue/3400/46817

EUSTAFOR, 2020. Members. https:/eustafor.eu/abouteustafor/members. Accessed 12 July 2020.

GDF, 2015. Oduna dayalı orman ürünlerinin satış usul ve esaslar1 [Sales procedures and principles of wood-based forest products]. Communiqué No. 303, Business and Marketing Department. https:/www.ogm.gov.tr/tr/ekutuphane/mevzuat/tebligler. Accessed 10 July 2019.

GDF, 2018. Strategic plan 2019-2023. https:/www.ogm. gov.tr/tr/stratejik-plan. Accessed 20 December 2018.

GDF, 2020. Forest Information System. https://orbis.ogm. gov.tr/orbis. Accessed 20 December 2020.

Hinkle D.E., Wiersma W., Jurs S.G., 2003. Applied statistics for the behavioral sciences, 5 th edn. Houghton Mifflin, Boston, $756 \mathrm{p}$.

İlkmen Ş.N., 1946. Ormancılıktaki devlet işletmeciliğinin sebepleri ve özel ormanlara müdahale meselesi [Reasons for state business in forestry and the issue of intervention to private forests]. Forest and Hunting Magazine 8:237-243.

Kaliszewski A., Młynarski W., 2020. Not only sale of wood: diversification of sources of revenues in selected European public forest enterprises. Folia Forestalia Polonica 62: 160-170. https://doi.org/10.2478/ffp2020-0016

Leefers A.L., Ghani A.N.A., 2014. Timber pricing. In Kant S., Alavalapati J. (ed.), Handbook of forest resource economics. Routledge, London, pp. 81-96.

Liubachyna A., Secco L., Pettenella D., 2017. Reporting practices of state forest enterprises in Europe. Forest Policy and Economics 78: 162-172. https://doi. org/10.1016/j.forpol.2017.01.019

Ok K., 1997 a. Devlet Orman İşletmelerinin Açık Artırmalı Satışlarının Etkileşimi [Interaction between auction sales of state forestry enterprises]. Journal of Eastern Mediterranean Forestry Research Directorate 3: 39-62.

Ok K, 1997 b. Aynı yaşlı ormanlarda kesim düzeninin ekonomik analizi [Economic analysis of harvest scheduling on even-aged forests]. Dissertation, İstanbul University, İstanbul, $228 \mathrm{p}$.

Olsson M.O., 2021. Changes in market behaviour among Russian forest enterprises. Europe-Asia Studies 73: 505-532. https://10.1080/09668136.2020.1752623

Öztürk A., Demirci U., Dikilitas K., 2019. Effect of production year on log sale prices: example in Artvin, Turkey. Kastamonu University Journal of Forestry 
Faculty 19: 342-349. https://doi.org/10.17475/ kastorman.662726

Saphores J.D., Vincent J.R., Marochko V., Abrudan I., Bouriaud L., Zinnes C., 2006. Detecting collusion in timber auctions: an application to Romania. Policy Research Working Paper, no 4105, World Bank, Washington DC, 58 p. https://openknowledge. worldbank.org/handle/10986/9263

Sekot W., 1998. The inter-farm comparison as an instrument of forest farm analysis. In Sekot W. (ed.), Contributions to the forest economics. Festschrift for Prof. Sagl. Series of publications by the Institute for Socio-Economics of Forestry and Wood Management, Vienna, pp. 221-242.
TurkStat, 2019. Domestic producer price index, NACE Rev.2 (2003=100). https://data.tuik.gov.tr/img/SVG/ excel.svg. Accessed 20 July 2019. 